\title{
EVALUATION OF FLOURS FROM ANCIENT VARIETIES OF WHEAT (EINKORN, EMMER, SPELT) USED IN PRODUCTION OF BREAD
}

\author{
- Research paper -
}

\author{
Justyna BELCAR*1, Anna SOBCZYK**, Tomasz R. SEKUTOWSKI***, Sławomir \\ STANKOWSKI ${ }^{* * * *}$, Józef GORZELANY*
}

\author{
*Department of Food and Agriculture Production Engineering, Collegium of Natural Sciences, \\ University of Rzeszow, St. Zelwerowicza 4, 35-601 Rzeszów, Poland \\ ** Department of Food Technology and Human Nutrition, Collegium of Natural Sciences, University \\ of Rzeszow, Zelwerowicza 4 St., 35-601 Rzeszow, Poland \\ *** Institute of Soil Science and Plant Cultivation, National Research Institute, Pulawy, Department \\ of Weed Science and Tillage Systems, Orzechowa 61 St., 50-540 Wroclaw, Poland \\ **** Department of Agroengineering, Faculty of Environmental Management and Agriculture, West \\ Pomeranian University of Technology in Szczecin, Pope Pawła VI 3 St., $71-459$ Szczecin, Poland
}

\begin{abstract}
The study investigates rheological properties of dough and baking process made from flour obtained by milling grains from ancient varieties of wheat (einkorn, emmer and spelt), compared to common wheat flour dough (Arkadia variety). The findings show that einkorn flour dough and emmer flour dough present poor tolerance to mechanical processing and prolonged fermentation. These types of dough should be mixed through relatively short, and fermentation time should not exceed 80 minutes for einkorn dough and 45 minutes in the case of emmer dough. In the case of spelt flour dough, the optimum duration of mechanical processing and fermentation amounted to 10 minutes and 60 minutes, respectively. In terms of technological and baking parameters, spelt flour was most similar to the flour obtained by milling conventional wheat, and the superiority of the former was in fact identified in the case of selected factors. A one-stage method was used in the baking process and the bread was then subjected to organoleptic and physicochemical assessments and to texture profile analysis (TPA). Measurements were also performed to determine the indicators reflecting the quality of the baking processes, including dough yield, baking loss and bread yield. The physical parameters of the bread produced were significantly related to the wheat variety. The loaves made from einkorn and spelt flour were of good quality, comparable to the bread made from the conventional wheat, while their baking quality indicators were satisfying. Bread dough made from emmer flour did not meet the required parameters mainly related to the organoleptic assessment and selected physical properties of the bread crumb. However, the one-stage production method should not be applied to doughs made from emmer flour. Given the specific characteristics of the breads produced from the ancient wheat varieties, including their pleasant taste and aroma, as well as attractive colour in the case of einkorn bread, these baked products may be an interesting addition to the assortment of breads on offer from bakeries, restaurants and agritourist farms.
\end{abstract}

Keywords: einkorn, emmer, spelt, dough rheology bread baking, physicochemical properties of bread, TPA

\section{INTRODUCTION}

Recent years have witnessed increasing popularity of ecological farming and organic foods produced without applying chemical fertilisers and crop protection. Wheat varieties most frequently grown in ecological farms include the relic crops, i.e. einkorn (Triticum monococcum), emmer (Triticum dicoccum) and spelt (Triticum aestivum ssp. spelta) (Kissing Kucek et al. 2017). Food products obtained

Received: 15.02.2021

Accepted in revised form: 14.05 .2021

${ }^{1}$ Corresponding author. E-Mail address: justyna.belcar@op.pl obtained from these are appreciated by more and more consumers, particularly in Europe, because of their specific taste, flavour and nutritional value. It is emphasised that grains of these varieties have higher contents of biologically active components, compared to conventional wheat, and gluten contained in them has primitive structure, unchanged by crop breeding (Geisslitz et al., 2018; Valli et al., 2018; Lomolino et al., 2017; Sahin et al., 2017; Sobczyk et al., 2017a; Krawczyk et al., 2008a). 
Einkorn (Triticum monococcum) is the oldest, diploid wheat variety, grown as far back as 10,000 years ago; it is cultivated mainly in chilly climates and in poor soils. It is native to the area of the Fertile Crescent in the Near East. Currently einkorn is also grown in France, India, Italy and Turkey (Stallknecht et al., 1996). Because of the high content of carotenoids, flour obtained from einkorn is yellowish in colour. The contents of gluten proteins are relatively high; however, they adversely affect the baking quality due to their viscosity and low flexibility. The dough gains stability after the baking process, therefore it should be placed in a baking pan (Marchand, 2014). Bread made from einkorn flour is a good source of antioxidants and phenols, constituting a good alternative for traditional baked products. Sapristein et al. (2012) and Troccoli and Codianni (2005) examined bread made from einkorn flour and reported that organoleptic assessment showed high sensory value of these products. Although wholemeal flour was used, the crumb was light in colour.

Derived from a cross between einkorn and wild grass, emmer (Triticum dicoccum) is a tetraploid wheat. Like einkorn, it originated in areas of today's Turkey, and nowadays it is still cultivated there in small amounts. Dough made from emmer (Triticum dicoccum) flour is more stable, compared to a product made from einkorn wheat. The contents of gluten proteins, mainly gliadin and glutenin, as well as the ratio at which they occur in the grains, determine the viscoelastic properties of dough made from emmer wheat flour. The gluten is tight and springy; however, the dough must be kneaded gently. Low volume of the loaf is observed in the baked goods. Given the fact that different emmer cultivars present varied baking quality, it is necessary to carefully select a cultivar to obtain flour which may effectively be used in baking industry and even in pasta production (Marchland, 2014).

Spelt (Triticum aestivum ssp. spelta) is a hexaploid wheat variety. It was grown since the ancient times in Europe and the Near East and only in the 20th century was replaced with other more productive varieties of common wheat. Today spelt is grown in ecological farms in many countries, e.g. Belgium, Austria, Germany, Italy, and Czechia. The content of wet gluten in spelt flour is higher than in flour obtained from common wheat, but the quality of this component is relatively low (Gambuś et al., 2018). Gluten contained in spelt wheat presents poor spreadability, which means its structure is not highly stable and does not retain carbon dioxide and water in the dough. Spelt flour dough presents poor elasticity and stability, and baked goods made from this dough have low volume (Krawczyk et al., 2008a).

Quality characteristics of baked goods are significantly affected by the method of dough preparation, which should match the type of flour and its baking potential. By optimising the fermentation process, it is possible to produce baked goods with appropriate quality characteristics, in particular fine aroma and long shelf life (Różyło \& Laskowski, 2009). For this purpose, it is worthwhile to carry out extensograph and fermentograph measurements of the raw material. By using a fermentograph it is possible to examine the behaviour of dough during expansion induced by yeast, and to assess this way the stability of the gluten network which retains carbon dioxide bubbles. These data, combined with extensograph properties, make it possible to define the duration of fermentation when dough achieves the optimum viscoelastic properties.

Flours produced from grains of einkorn, emmer and spelt cause problems in technological processes. Doughs made from these flours present low elasticity and strength. Therefore, technological recommendations resulting from rheological assessment of this type of dough may be helpful in designing production of goods containing these wheat flours. From the viewpoint of consumers, this may lead to greater availability of healthy products with good nutritional value (Guerrini et al., 2019). In order to determine baking quality of flour it is necessary to perform a laboratory test whereby bread is baked according to strictly defined rules. The way of inducing and continuing fermentation is the main criterion for distinguishing the methods of dough preparation and baking. Dough may be prepared using industrial yeast or by applying spontaneous fermentation carried out by microorganisms contained in the material subjected to the process. Most common in Poland, the onestage (direct) or two-stage method requires addition of yeast; although it is time consuming and labourintensive, the final products present better nutritional and sensory properties in many respects. The purposes of the study are: to compare rheological properties of flours obtained from ancient wheat varieties: einkorn, emmer and spelt; to prepare dough from flour obtained from ancient wheat varieties, and to perform a laboratory bread baking test; to assess the breads for the food industry needs. 


\section{MATERIAL AND METHODS}

\section{Material}

The material selected for the study comprised flours obtained by milling grains of einkorn - a local cultivar, emmer (the varieties Lemella) and spelt the varieties Wirtas. Grains of the ancient wheat varieties were produced at the Agricultural Experiment Station in Lipnik $\left(53^{\circ} 41^{\prime} \mathrm{N}, 14^{0} 97^{\prime} \mathrm{S}\right)$ in 2018. Flour used as a reference material was obtained by milling grains of wheat of Arkadia varieties, were produced at the SAN Farming Cooperative. The wheat grain harvested in 2018 was grown using medium intensive cultivation methods, by a producer located in the village of Studzian $\left(50^{\circ} 02^{\prime} 52^{\prime \prime} \mathrm{N}, 22^{0} 27^{\prime} 38^{\prime \prime} \mathrm{E}\right)$ in the Podkarpackie Region, Przeworsk District.

\section{Conditioning of the grain}

After they were purified, the ancient grains were conditioned up to the moisture content of $13.5 \%$, with the exception of wheat grain, of Arkadia cultivar because it had a water content of $14.05 \%$ (Belcar et al., 2020).

\section{Grain milling}

Flour $\mathrm{F}_{1}$ and bran $\mathrm{B}_{1}$ were obtained as a result of grain milling. There was still some flour in the bran $\mathrm{B}_{1}$ fraction, so the bran $\mathrm{B}_{1}$ was ground and sieved in Brabender Bran Duster; to obtain flour $F_{2}$ and bran B. Further analyses took into account flour which was a sum of the two fractions $\left(\mathrm{F}_{1}\right.$ and $\left.\mathrm{F}_{2}\right)$. Milling of the grain was made on Quadrumat Junior roller mill from Brabender (Belcar et al., 2020).

\section{Farinograph measurements of the flours}

Samples of flour for farinograph testing with a weight corresponding to the moisture content of the flour - $14 \%$ i.e. $300 \mathrm{~g}$ were prepared to obtain a dough with a consistency of $500 \mathrm{FU}$ (if the moisture content of the flour tested differed from 14\% then a correspondingly larger or smaller flour weight, indicated automatically by the apparatus, was used). The flour was placed in the kneader of the farinograph and a specified amount of distilled water at a temperature of $30^{\circ} \mathrm{C}$ was added. The procedure was repeated until dough consistency of $500 \mathrm{FU}$ (with acceptable deviation of $20 \mathrm{FU}$ ) was achieved, whereby the required amount of water was determined. The factors specified as a result of farinograph measurements, performed in accordance with the rules set forth by ICC (1992), included normal flour water absorption, dough development time and stability, dough resistance, degree of softening over time, and valorimetric value.

\section{Extensograph measurements of the flours}

The procedure of extensograph testing involved preparation of dough with a consistency of $500 \mathrm{FU}$, from the flours investigated, in the kneader of farinograph with a capacity of $300 \mathrm{~g}$. The dough was then subjected to autolysis in the chambers of extensograph for a specified duration, when the qualitative changes occurring at the time were assessed (ICC 1992). The dough was added kitchen salt to the dough in an amount representing $2 \%$ of the flour (in case of $300 \mathrm{~g}$ flour with $14 \%$ moisture or equivalent the quantity of salt is $6 \mathrm{~g}$ ). Brine is used to stabilise the dough. After the dough achieved the consistency of $500 \mathrm{FU}$, in the fiveth minute of the kneading process, the program of farinograph analysis was stopped. The dough was split into two chunks, $150 \mathrm{~g}$ each, and placed in the fermentation chamber of the extensograph, at a temperature of $30^{\circ} \mathrm{C}$. Subsequently the material was examined after 45, 90 and 135 minutes of the maturation, by analysis of stretching the dough.

\section{Fermentograph measurements of the flours}

The fermentation properties of the flour obtained from grains of einkorn, emmer, spelt as well as Arcadia common wheat were identified using a BZS SZ 2005 type laser fermentograph (from Sadkiewicz Instruments). The dough was made by mixing $140 \mathrm{~g}$ flour, $2.5 \mathrm{~g}$ yeast, $2 \mathrm{~g}$ sodium chloride and $80 \mathrm{~cm}^{3}$ water (to achieve consistency of approximately $350 \mathrm{FU}$ ). The doughs were made using JŻ 750 type laboratory kneader, for a duration required to obtain an optimum structure. The kneading time totalled at 5 minutes (with rotation speed I and II applied for 2.5 minutes each). Subsequently, the dough was subjected to fermentation in the fermentograph chamber, at a temperature of $35^{\circ} \mathrm{C}$. The above process was continued until the dough volume curve exceeded the critical point corresponding to the optimum volume increase.

\section{Bread baking test}

The bread baking test was carried out in accordance with the one-stage method, in compliance with the recommendations of the Bakery Institute in Berlin (Soltysek, 2011). The dough consisted of flour, water, yeast and salt. The ingredients were combined in a bowl of a multifunctional food processor KU2-3E with dough hooks attached; to achieve uniform consistency, the dough was kneaded for 2 minutes at speed I, and for 1 minute at speed II, and dough resting time of 45 seconds was applied. After the kneading was complete (uniform consistency was achieved) the dough was placed in a proofing chamber. All the types of dough 

down (fermentation temperature $-30^{\circ} \mathrm{C}$ ). The process of working the dough to remove excess $\mathrm{CO}_{2}$, commonly referred to as punching down, was performed once only, for 1 minute. After the punch down the dough was again placed in the proofing chamber for $30 \mathrm{~min}$. After the one-hour long fermentation process was completed, the dough was weighed and divided into $250 \mathrm{~g}$ chunks. The chunks were formed manually and placed into laboratory test baking pans greased with edible oil. Water was brushed over the top layer of the dough and the pans with the dough were placed into the proofing chamber, to allow the dough to rise; the optimum duration of proofing varied depending on the type of flour used in the dough. After the proofing process was completed, the pans with dough were placed into a chamber of a modular electric oven from Sveba Dahlen, equipped with a ceramic plate. The following baking parameters were used: temperature inside the chamber $-230^{\circ} \mathrm{C}$, the circulation of front and top heat at setting 3 , and bottom heat at setting 7 . The baking time differed relative to the type of dough, the minimum duration amounting $30 \mathrm{~min}$. The baking process was carried out at full-level steaming within the chamber during the initial $30 \mathrm{~s}$. After the loaves achieved the required properties (the desirable colour on the surface of the bread, as well as fragrance) they were removed from the oven and punctured to check whether they were fully baked ("clean toothpick" method). The breads were then wetted with water were left to ferment for 30 minutes before punch-

and weighed immediately after that. The baked samples were left for 24 hours at a room temperature.

\section{Determination of baking process quality indicators}

Baking process quality indicators were assessed by determining the dough yield, baking loss and bread yield, based on the methodology described by Jakubczyk (1974).

\section{Determination of physical and chemical parameters of bread}

Bread moisture content was assessed using a dryer method; for this purpose $5 \mathrm{~g}$ samples of bread crumb were collected (with an accuracy of $0.01 \mathrm{~g}$ ) and were placed in open metal weighing dishes of a Binder dryer oven. The following parameters of the drying process were applied: temperature of $130^{\circ} \mathrm{C}$, drying time -1 hour, and standard profile. After the drying process was completed, the weighing dishes were placed in a desiccator, and after colling down they were weighed (Krełowska - Kułas, 1993).

The bread volume was determined in compliance with the methodology described by Jakubczyk (1974). The bread volume was determined by measuring the volume of grains displaced by the loaf put into the testing chamber of $\mathrm{Sa}-\mathrm{Wy}$ apparatus from ZBPP Sadkiewicz Instruments. Volume of bread made from $100 \mathrm{~g}$ of flour was calculated following the formula (1):

$$
\text { volume of bread from } 100 \mathrm{~g} \text { flour }=\frac{\text { bread volume } * \text { dough yield }}{\text { weight of dough formed for baking }}\left[\mathrm{cm}^{3}\right]
$$

The volume index was calculated based on the volume of bread from $100 \mathrm{~g}$ flour, in accordance with the methodology described by Jakubczyk and Haber (1983).

Specific weight of bread crumb was determined by weighing a sample of known volume cut out from the central part of the crumb. The sample was collected using a cylindrically shaped cutting probe with a capacity of $22 \mathrm{~cm}^{3}$. Specific weight was calculated according to the formula (2):

$$
\mathrm{n}=\frac{\mathrm{m}_{\mathrm{w}}}{\mathrm{V}_{\mathrm{w}}}
$$

where:

$\mathrm{n}$ - specific mass of crumb $\left[\mathrm{g} \cdot\left(\mathrm{cm}^{3}\right)^{-1}\right]$

$\mathrm{m}_{\mathrm{w}}-$ mean weight for a given type of bread $[\mathrm{g}]$

$\mathrm{V}_{\mathrm{w}}$ - volume of the cylinder $\left[22 \mathrm{~cm}^{3}\right]$

\section{Texture Profile Analysis (TPA)}

The method applied for Texture Profile Analysis (TPA) imitates the process of human mastication. Consists in double squeezing a given food sample by a flat plate with a diameter greater than that of the tested sample. The test was to squeeze twice samples in the central part of the slice with a thickness of $3 \mathrm{~cm}$ with a mandrel with a diameter of $20 \mathrm{~mm}$, with a travel speed of $2 \mathrm{~mm} \mathrm{~min}^{-1}$. The interval between the cycles was $2 \mathrm{~s}$, a degree compression $-3 \mathrm{~mm}$. The related measurements, performed using Brookfield CT3 texture analyzer, were carried out in nine replications (according to Student's $t$ test) after 24 hours for baking, and took into account the following parameters: hardness, adhesiveness, cohesiveness, springiness (elasticity), gumminess and chewiness.

\section{Statistical analysis}

The statistical analysis was performed using Statistica 13.3. A analysis of variance (ANOVA) was applied, with significance level defined as $\alpha=$ 0.05 , taking into account the specific properties determining properties of the flour relative to the wheat variety and baking quality of flour. The mean values were compared using Tukey HSD test. The texture profiles were evaluated using Least Significant Difference (LSD) test. 


\section{RESULTS AND DISCUSSION}

Instrumental methods of assessing rheological properties of wheat flour dough make it possible to identify flour water absorption and to examine behaviour of dough in the process of kneading and during fermentation (Dąbkowska 2009). Farinograph measurements showed that the normal consistency of the dough was in the range of $493-$ 513 FU (Table 1).

The relevant flours did not differ significantly as regards normal water absorption, except for emmer flour which was found with the highest value of this parameter, amounting to $68.30 \%$. This may be associated with the particularly high content of gluten with good water absorption capacity in this sample (59.60\%) (Belcar et al., 2020). Water absorption in einkorn flour and in spelt flour amounted to $63.50 \%$, and $60.30 \%$, respectively. Similar values were identified by Geisslitz et al. (2018) who reported mean normal water absorption of $58.60-62.50 \%$ in einkorn flour, and 60.50$63.90 \%$ in emmer flour. Normal water absorption in spelt flour, investigated by Krawczyk et al. (2008a, 2008 b) was in the range from 56.00 to $62.50 \%$. Similar values in the range of $58.05-61.95 \%$ were reported by Filipčev et al. (2014), as well as by Sobczyk et al. (2017a), Macaroni et al. (2002) and Achremowicz et al. (1999). Normal water absorption in spelt flours, as demonstrated by Ceglińska (2003), can reach values up to $65.00 \%$, while Geisslitz et al. (2018) reported the related findings in the range of $60.50-66.60 \%$.

Dough development times identified for einkorn and emmer flours were similar (2.70 and $2.50 \mathrm{~min}$ respectively), while in the case of the other wheat varieties they differed significantly. Flour obtained from einkorn is weak, with short development time and very low stability of only $1.70 \mathrm{~min}$, which in the present study was linked with a significant decrease in the dough quality immediately after normal consistency (493 FU) was achieved. The findings, which show high degree of softening (140 FU) and consequently low resistance, suggest that einkorn dough requires gentle mechanical processing for up to $4.4 \mathrm{~min}$. These data, however, provide evidence for very poor quality of gluten network in the dough, ultimately showing low technological value of this flour. Geisslitz et al. (2018) in the case of einkorn flour samples identified development time ranging from 1.70 to $3.90 \mathrm{~min}$ and highly varied stability time in the range of $0.20-14.20 \mathrm{~min}$.

Emmer flour, like einkorn flour, is weak, with short development time and with stability time of 2.90 min. The study by Geisslitz et al. (2018) in the case of flour from this wheat variety reported development time of 2.90-5.00 minutes, and very short stability time $(0.20-0.80 \mathrm{~min})$. The current findings show that, in comparison to einkorn flour, the flour from emmer wheat presented significantly higher stability time and lower degree of softening. Resistance, however, was relatively low (5.4 min), which reflects poor quality of gluten. Hence, the emmer wheat flour subjected to the tests appears to present low baking quality.

The flour obtained by milling spelt grain was found with good baking quality, long development time of $4.20 \mathrm{~min}$ and stability time of $6.50 \mathrm{~min}$. The results show high resistance of the dough to kneading (4-6 minutes longer than the tolerance of the other doughs). Compared to flours from the other ancient wheat varieties, spelt flour presents significantly better rheological properties. As emphasised by Krawczyk et al. (2008a) a longer time during which the dough resists the mixing in a relatively stable manner corresponds to lower softening and consequently to higher technological value of the flour. In another study Krawczyk et al. (2008b) assessed spelt flours and reported development time of $3.20-5.00 \mathrm{~min}$, and stability time ranging from 2.00 to $4.60 \mathrm{~min}$. Spelt flours examined by Sobczyk et al. (2017a) were described by development time in the range of $1.70-5.80 \mathrm{~min}$ and stability of 2.00$7.90 \mathrm{~min}$; similar development times and stability times were reported by Geisslitz et al. (2018). Spelt breeding lines investigated by Macaroni et al. (2002) and Achremowicz et al. (1999) produced flours with short stability (1-3 $\mathrm{min})$; conversely Krawczyk et al. (2008a) and Ceglińska (2003) identified long development time in spelt flours, amounting to approx. $9.5 \mathrm{~min}$. Longer dough development and stability times (i.e. higher resistance to mixing) correspond to a longer duration of kneading required, consequently spelt flour dough may be subjected to more intensive mixing, compared to the other ancient wheat varieties. In fact, the present study shows that the former presents significantly higher tolerance to mechanical processing than the dough from flour obtained from common wheat of Arkadia variety. The stronger the wheat the higher its valorimetric value (Brabender 2008). In the current study spelt flour was found with the highest value of 85.0, this way presenting an advantage over the other varieties. In the study by Krawczyk et al. (2008b) valorimetric value of spelt flours ranged from 69 to 173. As regards this factor, the flours obtained in the present study by milling grains of emmer wheat and common wheat did not differ significantly, while the product of einkorn grain milling was considerably poorer (with valorimetric value of 32). 
Table 1. Farinograph measurements of flours obtained from grains of ancient wheat varieties and Arkadia common wheat $(\bar{x} \pm \mathrm{SD})$

\begin{tabular}{|c|c|c|c|c|}
\hline Characteristics & Einkorn flour & Emmer flour & Spelt flour & Common wheat flour (K) \\
\hline Consistency [FU] & $493.00^{\mathrm{a}} \pm 8.08$ & $496.00^{\mathrm{a}} \pm 6.93$ & $498.00^{\mathrm{a}} \pm 5.77$ & $513.00^{\mathrm{a}} \pm 6.35$ \\
\hline Normal water absorption [\%] & $63.50^{\mathrm{b}} \pm 1.15$ & $68.30^{\mathrm{a}} \pm 0.98$ & $60.30^{\mathrm{b}} \pm 1.10$ & $59.60^{\mathrm{b}} \pm 0.92$ \\
\hline Dough development time[min] & $2.70^{\mathrm{b}} \pm 0.05$ & $2.50^{\mathrm{b}} \pm 0.06$ & $4.20^{\mathrm{a}} \pm 0.06$ & $2.00^{\mathrm{c}} \pm 0.06$ \\
\hline Dough stability time [min] & $1.70^{\mathrm{d}} \pm 0.03$ & $2.90^{\mathrm{c}} \pm 0.03$ & $6.50^{\mathrm{a}} \pm 0.29$ & $5.00^{\mathrm{b}} \pm 0.32$ \\
\hline Resistance [min] & $4.40^{\mathrm{d}} \pm 0.03$ & $5.40^{\mathrm{c}} \pm 0.03$ & $10.70^{\mathrm{a}} \pm 0.29$ & $7.00^{\mathrm{b}} \pm 0.32$ \\
\hline Degree of softening [FU] & 140.00 & 94.00 & 0.00 & 101.00 \\
\hline Valorimetric value & $32.00^{\mathrm{c}} \pm 1.15$ & $51.00^{\mathrm{b}} \pm 1.73$ & $85.00^{\mathrm{a}} \pm 3.46$ & $58.00^{\mathrm{b}} \pm 2.31$ \\
\hline
\end{tabular}

$*$ the varied letters in the verses show significance of the differences at $\alpha=0.05$

\section{Extensograph measurements of the flours}

Dough properties (Table 2.) changed with longer fermentation time. Einkorn flour dough was found with similar total energy during the three measurements, however there was a visible tendency for decrease: from $26.0 \mathrm{~cm}^{2}$ after $45 \mathrm{~min}$ fermentation to $22.0 \mathrm{~cm}^{2}$ after $135 \mathrm{~min}$ (Table 2.). Resistance of dough to extension in the consecutive measurements decreased while dough extensibility remained at a similar level. The findings reflect poor extensibility and elasticity of einkorn flour dough. This type of dough behaves in a way resembling clay, it easily breaks, and carbon dioxide produced during fermentation is rapidly released and evaporates. After the dough is formed, it retains its spherical shape, it is slack and compact (Brabender 2009).

In the case of emmer flour dough the three measurements (after 45, 90 and $135 \mathrm{~min}$ ) showed very similar values of total energy from 32.0 to 36.0 $\mathrm{cm}^{2}$ (Table 2.). Resistance of dough to extension increased in the consecutive measurements. Resistance ratio was slightly higher after the final stage of fermentation, but was still very low. The results of extensograph measurements show that emmer flour dough is wet, loose, with insufficient elasticity, while emmer flour presents poor baking properties. The weak dough structure cannot retain carbon dioxide produced, as a result of which it is difficult to optimise the fermentation process. Fermentation occurs relatively quickly, but the dough remains flat because it easily sinks, even if the time was exceeded only slightly (Brabender 2009). Emmer flour dough should be left to ferment only for a short time, up to $45 \mathrm{~min}$. Due to its viscosity it is not suitable for industrial kneaders, but it can be kneaded manually. Preliminary tests carried out by these authors show that the latter method allows to obtain satisfactory quality of the mixture. Manual methods of dough processing are still irreplaceable in bakeries specialising in traditional products, in restaurants or in agritourist establishments. These are places where bread and other products made from emmer and other relic crops nowadays are perceived as an attractive and healthy option on offer.

Total energy in spelt flour dough was found at a far higher level, compared to the samples made from the two older wheat varieties. The changes in this factor observed during autolysis of spelt flour dough were statistically non-significant, however there was a notable decrease in energy after the third stage of fermentation (Table 2.). Sobczyk et al. (2017a) investigated various breeding lines of spelt wheat, and reported total energy ranging from $24.0 \mathrm{~cm}^{2}$ to $76.0 \mathrm{~cm}^{2}$ after 45 minutes, $15.0-83.0 \mathrm{~cm}^{2}$ after 90 minutes, and $11.0-91.0 \mathrm{~cm}^{2}$ after 135 minutes of the analyses. In the current study resistance of spelt flour dough to extension decreased in the consecutive measurements and was in the range of $250-230 \mathrm{EU}$, while its extensibility increased over time. Similar mean extensibility of spelt flour dough (218.5 mm) was found by Filipčev et al. (2014), who also reported far lower mean resistance to extension amounting to 132.5 EU. Conversely, Sobczyk et al. (2017a) identified far broader ranges of these two parameters in spelt flour dough: resistance to extension after $45 \mathrm{~min}$ was in the range of 85.0-327.0 EU, after $90 \mathrm{~min}-61.0-352.0 \mathrm{EU}$, after $135 \mathrm{~min}$ - 42.0-410.0 EU; extensibility after 45 min ranged from 139.0 to $227.0 \mathrm{~mm}$, after $90 \mathrm{~min}-$ from 113.0 to $207.0 \mathrm{~mm}$, and after $135 \mathrm{~min}$ - from 130.0 to $220.0 \mathrm{~mm}$. The current findings suggest that spelt flour doughs should be left to ferment for up to $90 \mathrm{~min}$, because measurements carried out at that time showed the highest values of both energy and resistance ratio, the latter value being a resultant of resistance and extensibility. The dough made from spelt wheat was moist, with good plasticity and extensibility. Even if dough processing is based on a single phase but includes fermentation continued for one hour (maximum 1.5 hour), where the dough is punched down once at the most, the bread produced should have sufficient volume and porosity. The flour obtained from spelt of Wirtas variety may effectively be used in bread mixtures in combination with strong flours, and in production of small-size baked goods and most types of confectionaries. 
Table 2. Extensograph measurements of flours obtained from grains of ancient wheat varieties and Arkadia common wheat $(\bar{x} \pm \mathrm{SD})$

\begin{tabular}{|c|c|c|c|c|c|c|c|c|c|c|c|c|}
\hline \multirow[b]{3}{*}{$\begin{array}{l}\text { Characteri } \\
\text { stics }\end{array}$} & \multicolumn{12}{|c|}{ Fermentation time [min] } \\
\hline & \multicolumn{4}{|c|}{45} & \multicolumn{4}{|c|}{90} & \multicolumn{4}{|c|}{135} \\
\hline & $\begin{array}{l}\text { Einkorn } \\
\text { flour }\end{array}$ & $\begin{array}{l}\text { Emmer } \\
\text { flour }\end{array}$ & $\begin{array}{l}\text { Spelt } \\
\text { flour }\end{array}$ & $\begin{array}{l}\text { Comm } \\
\text { on } \\
\text { wheat } \\
\text { flour }\end{array}$ & $\begin{array}{l}\text { Einkor } \\
\mathrm{n} \text { flour }\end{array}$ & $\begin{array}{l}\text { Emmer } \\
\text { flour }\end{array}$ & $\begin{array}{l}\text { Spelt } \\
\text { flour }\end{array}$ & $\begin{array}{l}\text { Comm } \\
\text { on } \\
\text { wheat } \\
\text { flour }\end{array}$ & $\begin{array}{l}\text { Einkor } \\
\mathrm{n} \text { flour }\end{array}$ & $\begin{array}{l}\text { Emmer } \\
\text { flour }\end{array}$ & $\begin{array}{l}\text { Spelt } \\
\text { flour }\end{array}$ & $\begin{array}{l}\text { Com } \\
\text { mon } \\
\text { wheat } \\
\text { flour }\end{array}$ \\
\hline $\begin{array}{l}\text { Total energy } \\
{\left[\mathrm{cm}^{2}\right]}\end{array}$ & $\begin{array}{l}26.0^{\mathrm{c}} \pm \\
0.92 \\
\end{array}$ & $\begin{array}{l}32.0^{\mathrm{c}} \pm \\
1.04\end{array}$ & $\begin{array}{l}97.0^{\mathrm{a}} \pm \\
2.30\end{array}$ & $\begin{array}{l}80.0^{\mathrm{b}} \pm \\
2.89 \\
\end{array}$ & $\begin{array}{l}24.0^{\mathrm{d}} \pm \\
1.15\end{array}$ & $\begin{array}{l}36.0^{\mathrm{c}} \pm \\
1.50\end{array}$ & $\begin{array}{l}99.0^{\mathrm{a}} \pm \\
2.89\end{array}$ & $\begin{array}{l}85.0^{\mathrm{b}} \pm \\
2.02 \\
\end{array}$ & $\begin{array}{l}22.0^{\mathrm{d}} \pm \\
0.98\end{array}$ & $\begin{array}{l}36.0^{c} \pm \\
1.15 \\
\end{array}$ & $\begin{array}{l}89.0^{\mathrm{a}} \pm \\
2.31 \\
\end{array}$ & $\begin{array}{l}80.0^{\mathrm{b}} \\
\pm 2.71 \\
\end{array}$ \\
\hline $\begin{array}{l}\text { Resistance } \\
\text { of dough to } \\
\text { extension } \\
{[\mathrm{EU}]}\end{array}$ & $\begin{array}{l}141.0^{\mathrm{b}} \pm \\
3.46\end{array}$ & $\begin{array}{l}108.0^{c} \\
\pm 3.46\end{array}$ & $\begin{array}{l}250.0^{\mathrm{a}} \pm \\
5.20\end{array}$ & $\begin{array}{l}242.0^{\mathrm{a}} \\
\pm 3.75\end{array}$ & $\begin{array}{l}130.0^{\mathrm{c}} \\
\pm 3.46\end{array}$ & $\begin{array}{l}122.0^{\mathrm{c}} \pm \\
2.89\end{array}$ & $\begin{array}{l}244.0^{\mathrm{b}} \\
\pm 5.77\end{array}$ & $\begin{array}{l}268.0^{\mathrm{a}} \\
\pm 1.76\end{array}$ & $\begin{array}{l}120.0^{\mathrm{d}} \\
\pm 2.48\end{array}$ & $\begin{array}{l}138.0^{\mathrm{c}} \pm \\
3.23\end{array}$ & $\begin{array}{l}230.0^{\mathrm{b}} \\
\pm 3.46\end{array}$ & $\begin{array}{l}260.0^{\mathrm{a}} \\
\pm 3.00\end{array}$ \\
\hline $\begin{array}{l}\text { Extensibility } \\
{[\mathrm{mm}]}\end{array}$ & $\begin{array}{l}133.0^{c} \pm \\
2.31\end{array}$ & $\begin{array}{l}195.0^{\mathrm{b}} \\
\pm 2.89\end{array}$ & $\begin{array}{l}209.0^{\mathrm{a} \pm} \\
4.62\end{array}$ & $\begin{array}{l}182.0^{0 \mathrm{ab}} \\
\pm 3.75\end{array}$ & $\begin{array}{l}128.0^{c} \\
\pm 2.60\end{array}$ & $\begin{array}{l}203.0^{\mathrm{a} \pm} \\
4.04\end{array}$ & $\begin{array}{l}213.0^{\mathrm{a}} \\
\pm 6.35\end{array}$ & $\begin{array}{l}175.0^{\mathrm{b}} \\
\pm 4.33\end{array}$ & $\begin{array}{l}131.0^{\mathrm{c}} \\
\pm 3.18\end{array}$ & $\begin{array}{l}185.0^{\mathrm{b} \pm} \\
4.04\end{array}$ & $\begin{array}{l}216.0^{\mathrm{a}} \\
\pm 4.06\end{array}$ & $\begin{array}{l}174.0^{\mathrm{b}} \\
\pm 3.00\end{array}$ \\
\hline $\begin{array}{l}\text { Maximum } \\
\text { resistance at } \\
\text { breaking } \\
\text { point [EU] }\end{array}$ & $\begin{array}{l}182.0^{c} \pm \\
3.70\end{array}$ & $\begin{array}{l}111.0^{\mathrm{b}} \\
\pm 2.48\end{array}$ & $\begin{array}{l}321.0^{\mathrm{a}} \pm \\
6.70\end{array}$ & $\begin{array}{l}308.0^{\mathrm{a}} \\
\pm 5.21\end{array}$ & $\begin{array}{l}170.0^{\mathrm{b}} \\
\pm 3.75\end{array}$ & $\begin{array}{l}123.0^{\mathrm{c}} \pm \\
2.89\end{array}$ & $\begin{array}{l}334.0^{\mathrm{a}} \\
\pm 6.52\end{array}$ & $\begin{array}{l}343.0^{\mathrm{a}} \\
\pm 5.77\end{array}$ & $\begin{array}{l}167.0^{\mathrm{c}} \\
\pm 3.18\end{array}$ & $\begin{array}{l}139.0^{\mathrm{d}_{ \pm}} \\
4.04\end{array}$ & $\begin{array}{l}307.0^{\mathrm{a}} \\
\pm 4.06\end{array}$ & $\begin{array}{l}325.0^{\mathrm{b}} \\
\pm 3.00\end{array}$ \\
\hline $\begin{array}{l}\text { Resistance } \\
\text { ratio }\end{array}$ & $\begin{array}{l}1.1^{\mathrm{c}} \pm \\
0.06\end{array}$ & $\begin{array}{l}0.6^{\mathrm{d}} \pm \\
0.02\end{array}$ & $\begin{array}{l}1.5^{\mathrm{b}} \pm \\
0.02\end{array}$ & $\begin{array}{l}1.7^{\mathrm{a}} \pm \\
0.03\end{array}$ & $\begin{array}{l}1.0^{c} \pm \\
0.02\end{array}$ & $\begin{array}{l}0.6^{\mathrm{d}} \pm \\
0.02\end{array}$ & $\begin{array}{l}1.6^{\mathrm{b}} \pm \\
0.03\end{array}$ & $\begin{array}{l}2.0^{\mathrm{a}} \pm \\
0.03\end{array}$ & $\begin{array}{l}0.9^{c} \pm \\
0.02\end{array}$ & $\begin{array}{l}0.8^{\mathrm{c}} \pm \\
0.01\end{array}$ & $\begin{array}{l}1.4^{\mathrm{b}} \pm \\
0.02\end{array}$ & $\begin{array}{l}1.9^{\mathrm{a}} \pm \\
0.06\end{array}$ \\
\hline
\end{tabular}

$*$ the varied letters in the verses show significance of the differences at $\alpha=0.05$

Analysis of the data presented in Table 2, related to common wheat flour and spelt flour shows clear similarities between these two. It was theoretically assumed that the control dough had better structure given its significantly higher resistance ratio at the given time points during fermentation.

The difference, although statistically significant, was too small to make it necessary to introduce separate technological recommendations for both types of dough. Both spelt flour dough and common wheat flour dough should be left to ferment for not more than 90 minutes, with a single punch-down at the most.

\section{Fermentograph measurements of the flours}

Fermentograph testing made it possible to measure the following parameters describing the process of expansion: time to achieve critical point, volume of gases retained in dough corresponding to dough volume, volume of gases released outside the dough (losses) and total volume of gases produced during fermentation. Critical time corresponds to optimum fermentation time, most suitable to start the baking process. Fermentation time exceeding the optimum duration is not effective because during that prolonged period more gases are released than retained (Sobczyk et al., 2017b). No significant difference was identified in critical times between the doughs obtained from spelt and common wheat (58 and 60 min, respectively; Fig. 3,4). These two types of dough were found with similar volume at critical points and total volume of gases produced during fermentation. However, spelt flour dough should be described as weaker because the volume of carbon dioxide lost was two times bigger than in the common wheat dough. Compared to the dough from spelt and common wheat flours, einkorn flour dough was found with similar volumes of gases retained $\left(236 \mathrm{~cm}^{3}\right.$; Figure 1.) and gases produced $\left(271 \mathrm{~cm}^{3}\right)$ as well as significantly longer time to critical point $(72 \mathrm{~min})$. These favourable characteristics will not be reflected in technological practice because a considerable part of the carbon dioxide produced will lost. The loss amounted to 35 $\mathrm{cm}^{3}$, which reflects poor structure of this type of dough. For the same reason einkorn flour dough must be left to ferment only for a short time. Fermentation capacity in the case of emmer four dough was significantly poorer, compared to the other samples. In fact, no loss of carbon dioxide was observed, which means that the dough retained all the gases produced during fermentation process, however the latter value was very low - at the critical point, after 36 minutes of the fermentation process, it amounted to as little as $103 \mathrm{~cm}^{3}$ (Figure 2).

As a result of einkorn flour dough fermentation (Table 3.) the optimum volume was obtained in the critical time of 72 minutes. However, the relevant graph (Figure 1.) shows that it was only after 80 minutes of the fermentation process that there was an increase in the amount of gas evaporated, or lost. Based on extensograph measurements, the maximum fermentation time for einkorn flour dough was defined as $90 \mathrm{~min}$. By comparing the results of fermentograph and extensograph measurements it was assumed that the optimum fermentation time in the case of einkorn flour dough amounted to 80 minutes.

Fermentograph measurements related to the dough made from flour obtained by milling emmer grains (Table 3.) showed a critical time of 36 minutes, 
which was consistent with the results of extensograph measurements suggesting that fermentation of emmer flour dough should not exceed 45 minutes. Furthermore, the relevant fermentation chart (Figure 2) shows that following 50-minute fermentation process there was a rapid increase in the volume of gases evaporated. Hence, it can be assumed that optimum fermentation process in the case of emmer flour dough should not exceed the time of 45 minutes.

Critical time of 58 minutes was identified in the case of spelt flour dough, however visible loss of carbon dioxide started after 65 minutes (Figure 3.); on the other hand, the extensograph measurements suggested that this type of dough should be left to ferment for 45 - 90 minutes. Ultimately it was assumed the optimum time was 60 minutes. The study by Sobczyk et al. (2017b) showed critical time in the range of 46-84 minutes in the relevant lines of spelt wheat.

Like in the case of the dough made from the ancient wheat flours, comparative analyses were carried out for the dough made from common wheat flour taking into account the results of extensograph (Table 2.), and fermentograph measurements (Table 3.) as well as fermentation chart (Figure 4), and the following values were identified: critical time of 60 min, start of gas evaporation - 67 minutes, extensograph optimum - maximum of 90 minutes. The optimum fermentation time was defined as 70 minutes.

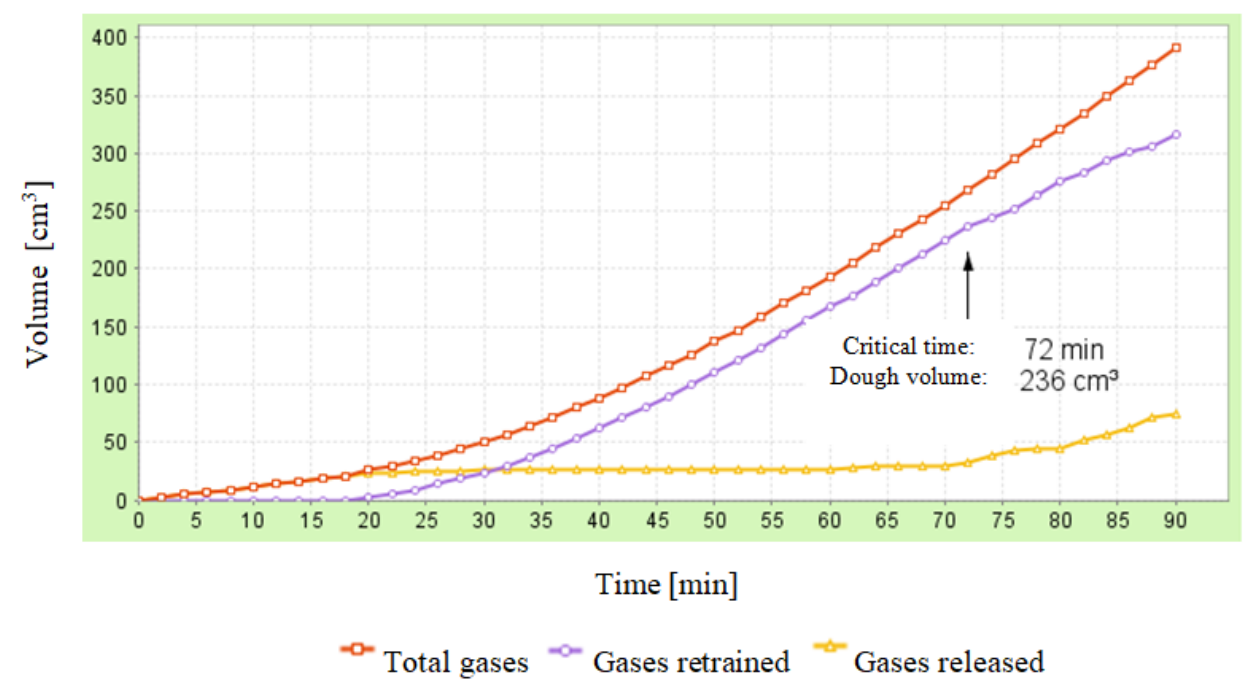

Figure 1. Fermentation chart for the dough from einkorn flour

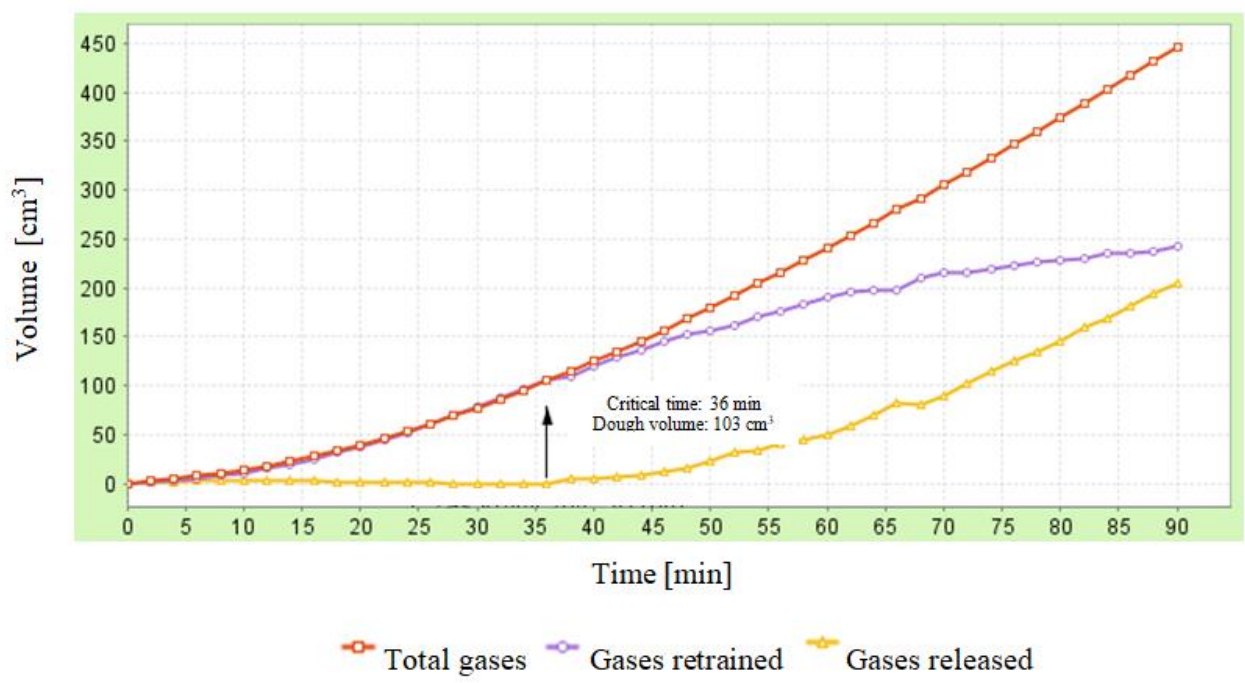

Figure 2. Fermentation chart for the dough from emmer flour 


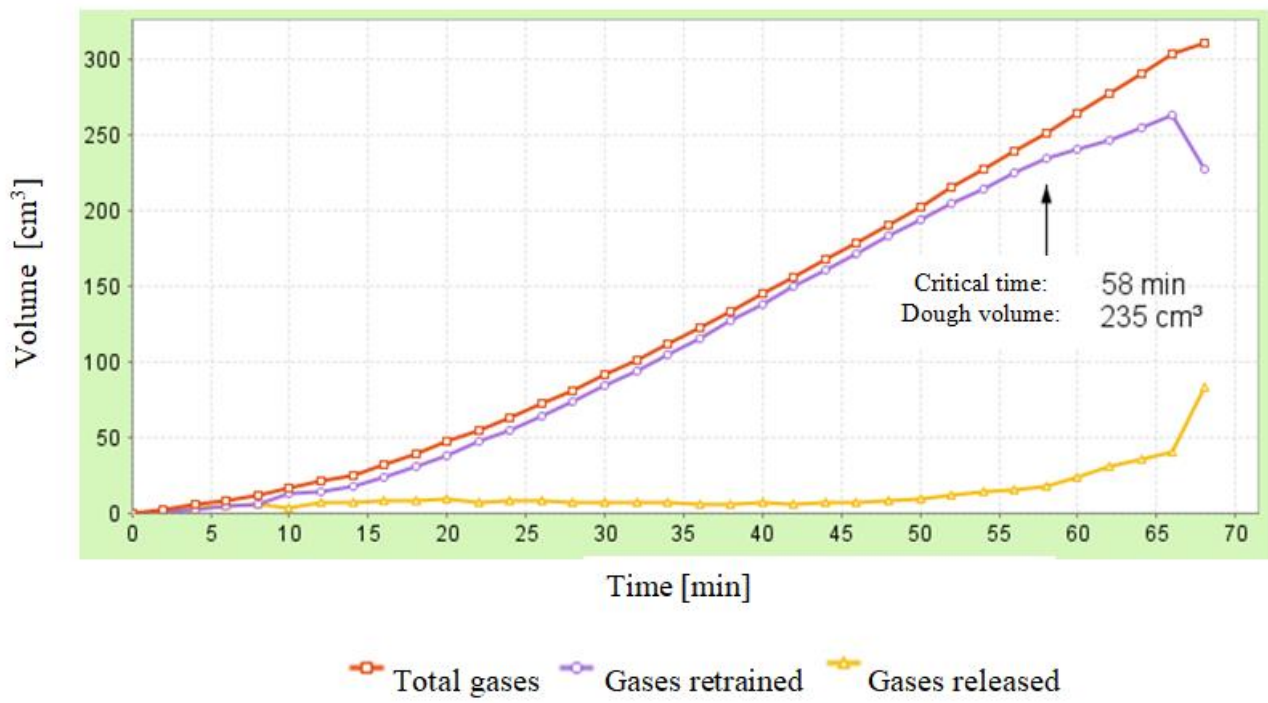

Figure 3. Fermentation chart for the dough from spelt flour

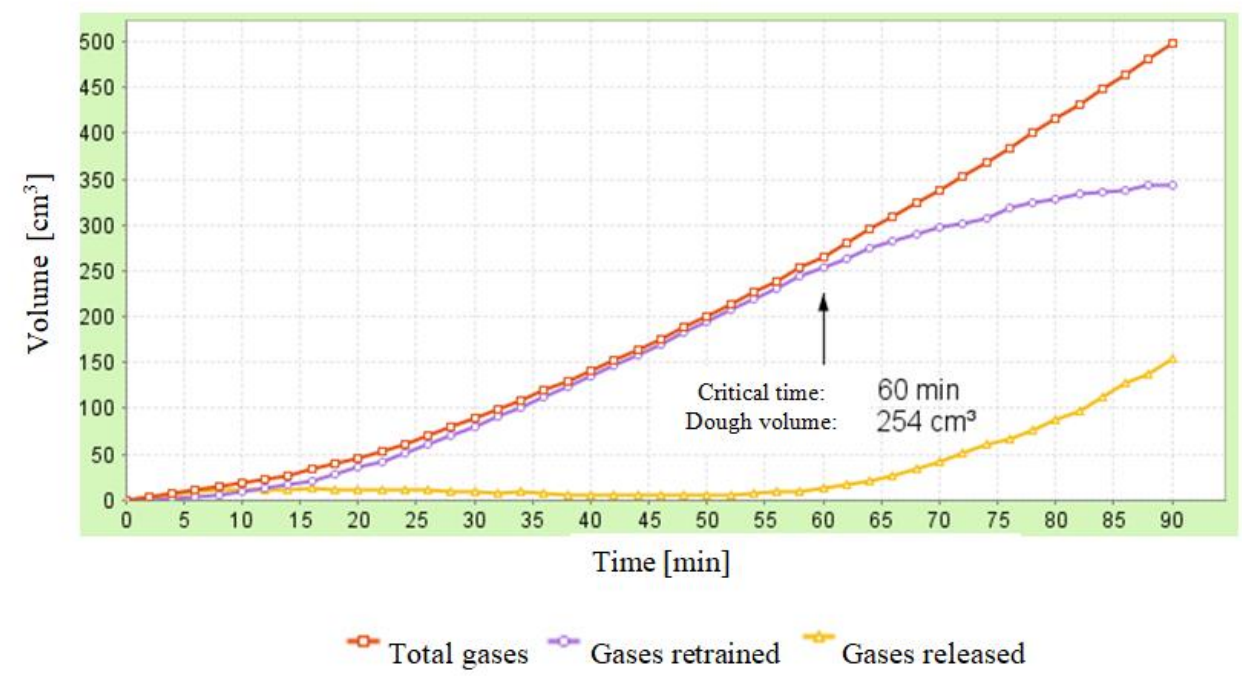

Figure 4. Fermentation chart for the dough from Arkadia common wheat flour

Table 3. Fermentograph measurements of flours obtained from grains of ancient wheat varieties and Arkadia common wheat $(\bar{x} \pm \mathrm{SD})$

\begin{tabular}{|c|c|c|c|c|}
\hline Characteristics & Einkorn flour & Emmer flour & Spelt flour & $\begin{array}{c}\text { Common wheat } \\
\text { flour (K) }\end{array}$ \\
\hline Critical time [min] & $72.0^{\mathrm{a}} \pm 1.73$ & $36.0^{\mathrm{c}} \pm 1.15$ & $58.0^{\mathrm{b}} \pm 1.73$ & $60.0^{\mathrm{b}} \pm 1.15$ \\
\hline $\begin{array}{c}\text { Volume of gases retained in } \\
\text { dough }\left[\mathrm{cm}^{3}\right]\end{array}$ & $236.0^{\mathrm{a}} \pm 5.77$ & $103.0^{\mathrm{b}} \pm 3.76$ & $235.0^{\mathrm{a}} \pm 4.62$ & $254.0^{\mathrm{a}} \pm 2.31$ \\
\hline $\begin{array}{c}\text { Total volume of gases } \\
\text { produced [cm } 3\end{array}$ & $271.0^{\mathrm{a}} \pm 8.66$ & $103.0^{\mathrm{b}} \pm 4.62$ & $250.0^{\mathrm{a}} \pm 7.50$ & $262.0^{\mathrm{a}} \pm 4.62$ \\
\hline $\begin{array}{c}\text { Volume of gases released } \\
\text { outside dough }\left[\mathrm{cm}^{3}\right]\end{array}$ & 35.0 & 0.0 & 15.0 & 8.0 \\
\hline
\end{tabular}

* the varied letters in the verses show significance of the differences at $\alpha=0.0$

Table 4. Effect of the type of flour on the result of the bread baking process $(\bar{x} \pm \mathrm{SD})$

\begin{tabular}{|c|c|c|c|}
\hline Type of flour & Dough yield [\%] & Baking loss [\%] & Bread yield [\%] \\
\hline Einkorn flour & $161.13^{\mathrm{a}} \pm 3.46$ & $11.56^{\mathrm{ab}} \pm 0.31$ & $137.96^{\mathrm{a}} \pm 3.36$ \\
\hline Emmer flour & $165.87^{\mathrm{a}} \pm 4.04$ & $13.63^{\mathrm{a}} \pm 0.45$ & $136.48^{\mathrm{a}} \pm 2.66$ \\
\hline Spelt flour & $168.61^{\mathrm{a}} \pm 4.61$ & $9.97^{\mathrm{ab}} \pm 1.20$ & $142.85^{\mathrm{a}} \pm 5.04$ \\
\hline Common wheat flour ('Arkadia') & $161.35^{\mathrm{a}} \pm 2.89$ & $9.88^{\mathrm{b}} \pm 0.92$ & $137.82^{\mathrm{a}} \pm 2.03$ \\
\hline
\end{tabular}

* the varied letters in the columns show significance of the differences at $\alpha=0.05$ 


\section{Baking process quality indicators}

Dough yield and bread yield did not differ significantly relative to the flour used in the baking process. Nevertheless, it is worthwhile to interpret the results because these values reflect the economic effectiveness of the process. The highest dough yield $(168.61 \%)$ was observed in the case of spelt wheat flour, and it corresponded to the highest bread yield (142.85\%), compared to all the other samples. The largest baking loss (13.63\%), corresponding to the lowest bread yield, was identified in the production of bread made from emmer wheat flour (Table 4). Baking loss in the case of emmer bread was far greater only if compared to the bread made from the common wheat flour. The losses generated during the production of einkorn and spelt breads were similar to those observed for the common wheat bread. Dough yield and bread yield in the case of einkorn flour were comparable to the control sample. A study by Majewska et al., (2007) identified dough yield from spelt flour in the range of 151-154\%. Gambuś et al., (2018) and Dąbkowska (2009) also carried out research in spelt bread and reported bread yield of $141.5-148.0 \%$, and 139.1-147.9\%, respectively. Slightly lower productivity of spelt flour was identified by Krawczyk et al., (2008a and 2008b) and Bojňanská \& Frančáková (2002), who reported spelt bread yield amounting to $133.0-135.0 \%$ and 133.0$141.0 \%$, respectively. A study by Stępniewska and Słowik (2016) investigating the quality of wheat breads, showed bread yield ranging from 137.0 to $141.0 \%$ (where bread made from common wheat of Arkadia cultivar was found with the yield of 140.0\%). Różyło (2010) established that by increasing the duration of dough kneading (from 2 to $5 \mathrm{~min}$, or even to $8 \mathrm{~min}$ ), and by continuing dough fermentation for $140 \mathrm{~min}$, it was possible to improve wheat bread yield.

According to Ambroziak (1999), baking loss depends on the shape and weight of dough chunk, type of flour and baking process parameters. Bread producers seek to decrease its value, however without technological loss it is impossible to achieve properly baked and formed crust. Greater specific surface of the bread of the same weight corresponds to higher baking loss. Research in spelt breads identified varied weight losses associated with the baking process. The lowest values (9.3$10.6 \%$ and 9.5-11.8\%) were reported by Krawczyk et al., (2008a, 2008b). Conversely, Majewska et al., (2007) as well as Bojňanská and Frančáková (2002) reported considerably higher baking losses in the range of $14.0-15.8 \%$, and $16.5-17.7 \%$, respectively. The baking processes conducted by Dąbkowska
(2009) were associated with weight losses in the broad range from 12.2 to $18.1 \%$.

\section{Physicochemical properties of bread}

The results of physicochemical assessment of the breads made from the flours of the relevant wheat varieties are shown in Table 5. No statistically significant differences were found between the breads with respect to moisture content of crumb. However, there were certain tendencies which are of importance for consumers. Moisture content of bread depends on a number of factors, including some connected with the dough recipe, baking process parameters and duration of storage. The content of water affects the texture of the bread (Dziki et al., 2011). The lowest and the highest moisture contents were found in the breads made from spelt flour $(45.60 \%)$, and emmer flour (49.20\%), respectively (Table 2.). These findings are consistent with the organoleptic assessment of the breads, according to which the crumb of spelt bread was rather dense, while the crumb of emmer bread was slightly moist. As specified in the norm $\mathrm{PN}-\mathrm{A}-74108$, moisture content of crumb should not be higher than $50 \%$, which means that the acceptable level of the parameter was not exceeded in any of the samples. The spelt breads baked by Gambuś et al., (2018) and Majewska et al., (2007) were found with moisture levels in the range of 41.6 - $44.2 \%$ and $42.0-43.5 \%$, respectively. Higher contents of water in spelt breads amounting to 45.9 - 48.2\%, were reported by Dąbkowska (2009), compared to the value of $48.71 \%$ identified by Michalska - Pożoga and Raczkowska (2012).

The mean weight of cold bread loaves made from flour obtained by milling grains of ancient wheat varieties amounted to $209.7 \mathrm{~g}$. The study of Gambus et al., (2018) showed the weight of cold bread from spelt flour ranging from 211.0 to $220.0 \mathrm{~g}$.

The highest loaf volume was found in the control sample $\left(862.5 \mathrm{~cm}^{3}\right)$. Lower volumes were identified in the loaves made from flour obtained from ancient wheat varieties, particularly in the bread from emmer flour - only $547.5 \mathrm{~cm}^{3}$. The values of this parameter in the case of einkorn and spelt bread did not differ significantly (with the mean of 609.0 $\mathrm{cm}^{3}$ ), but they were visibly higher compared to emmer bread. As regards the volume of the product from $100 \mathrm{~g}$ of flour, again the highest result was identified in the case of bread from common wheat flour $\left(555.8 \mathrm{~cm}^{3}\right)$. Significantly lower values of this parameter were observed in the baked products made from flour obtained from the ancient wheat varieties, with no significant differences between einkorn and spelt breads $\left(381.5\right.$ and $414.2 \mathrm{~cm}^{3}$ 
respectively). As regards this factor, the difference between einkorn and emmer breads was also nonsignificant. Notably, these two products failed to achieve a volume of $400 \mathrm{~cm}^{3}$ from $100 \mathrm{~g}$ of flour, defined as a minimum value for good quality bread. The lower values recorded for this parameter suggest it is necessary to modify the raw material or the baking method (Romakiewicz et al., 2013, Bojňanská and Frančáková, 2002).

Bread made from spelt flour, as reported by many researchers (Abdel - Aal et al., 1997; Bojňanská and Frančáková, 2002; Krawczyk et al., 2008b; Pruska - Kędzior et al., 2008; Zieliński et al., 2008), was found with lower volume of the product loaf volume, compared to bread from common wheat flour. The study by Gambuś et al., (2018) showed that the loaf volume of spelt bread was in the range from 586.0 to $713.0 \mathrm{~cm}^{3}$, while Majewska et al., (2007) reported lower volumes of loaves made from spelt flour ranging from 551.3 to $692.5 \mathrm{~cm}^{3}$. On the other hand, Corbellini et al., (1999), who focused on products made from einkorn flour, reported the loaf volume of einkorn bread in the broad range of 635.0 $-918.0 \mathrm{~cm}^{3}$, which is significantly more compared to the present findings. Volume of spelt breads per $100 \mathrm{~g}$ of flour was varied in studies published by specific authors. Krawczyk et al., (2008b) and Bojňanská and Frančáková (2002) reported low values of this parameter, in the range of 266.0-287.0 $\mathrm{cm}^{3}$ as well as $265.0-340.0 \mathrm{~cm}^{3}$, respectively. Likewise, Michalska-Pożoga and Raczkowska (2012) reported values below the norm $\left(369.42 \mathrm{~cm}^{3}\right.$ from $100 \mathrm{~g}$ of flour). Slightly higher mean rates were obtained by Majewska et al., (2007) and Dąbkowska (2009), who reported $374.8 \mathrm{~cm}^{3}$ and $380.0 \mathrm{~cm}^{3}$, respectively, with the volume of some samples exceeding the minimum value of $400.0 \mathrm{~cm}^{3}$ from $100 \mathrm{~g}$ of flour. Furthermore, the baked products obtained by Krawczyk et al., (2008a) were considerably varied as regards this factor which ranged from 373.5 to $450.9 \mathrm{~cm}^{3}$. In a study by Stępniewska and Słowik (2016) focusing on bread from common spring and winter wheat varieties, the volume of bread from $100 \mathrm{~g}$ of flour was in the range of $435.0-546.0 \mathrm{~cm}^{3}$, with the related value for Arkadia wheat flour amounting to $512.0 \mathrm{~cm}^{3}$, which was slightly lower than in the current study.

Statistical analysis of the results showed a lack of significant differences in the specific weight of crumb between the breads from the relevant ancient wheat varieties (from 0.35 for spelt to 0.38 einkorn and emmer), while these values were significantly higher than those identified for bread made from conventional wheat $(0.22)$. According to Jakubczyk (1974), lower specific weight of crumb corresponds to higher quality of the bread.
In summary, the values of the selected bread crumb parameters show unsatisfactory quality of the bread made from emmer flour. It appears that emmer bread cannot effectively be produced using the onestage (Berlin) method.

\section{Texture Profile Analysis (TPA)}

Texture-related characteristics of breads made from flour of ancient wheat varieties compared to the control sample (Table 6) included significantly higehr hardness, gumminess and chewiness; the quality of bread crumb was similar. Cohesiveness was the only differentiating property.

The textural term most commonly refers to crumb hardness, or the strength needed to first deflect the bread crumb. According to Romankiewicz et al., (2014), the value of this parameter does not depend on the method of dough preparation, and it changes (increases) over time, from the moment the bread is removed from the oven, for the following 24 hours. Lomolino et al., (2017) reported that einkorn bread was harder compared to bread made from flour obtained from common wheat; the authors argued this was due to the poorer ability of gluten to form and expand the gluten network and to retain fermentation gases in the dough. According to these authors, hardness of the crumb may be decreased if preparation of dough from einkorn flour begins with a fresh pre-ferment which will make the dough rise and will produce better effect compared to yeast. This was confirmed by their study - fresh starter increased the volume of bread and positively affected the crumb texture. Gambuś et al., (2018) report that the considerable hardness of spelt bread results from mechanical processing of the dough prior to baking. A $10 \%$ addition of wheat leaven or rye starter is recommended; however, these adversely affect the taste of the bread produced because of the increased acidity of the crumb. It may be assumed that in the case of small food outlets, where dough (including bread dough) is commonly kneaded by hand, the problem of hardness would not be so visible. As shown by Belcar et al., (2020), baking properties of spelt flour do not differ significantly from those of conventional wheat flour of medium quality. Manual processing may positively affect hardness of bread and delay the staling process (Romankiewicz, 2014). Springiness reflects to what degree bread crumb recovers its initial state after compressive force is applied, while cohesiveness is a ratio of work to be applied during crumb compression test performed in two repetitions. Gumminess corresponds to the energy needed to disintegrate food; it is determined indirectly by calculating the product of cohesiveness and hardness of bread crumb. On the 
other hand, chewiness corresponds to work determined based on the parameters of springiness and gumminess of bread. The highest chewiness and gumminess of bread crumb is observed 24 hours after the baking process. Higher values of these parameters correspond to lower attractiveness of bread for the consumer (Romankiewicz et al., 2014). Based on the TPA conducted in the current study it is very difficult to say which of the breads made from flour obtained from ancient wheat varieties presented the best texture-related parameters, because the results were very similar. However, it is possible to notice some trends differentiating the breads. Spelt bread, in addition to significantly lower cohesiveness, was also harder compared to all the other breads. This finding is consistent with the observation that crumb in this type of bread is rather dense. On the other hand, the lowest hardness, gumminess and chewiness were found in einkorn bread, and consequently this product was considered to present the best quality. By comparison, the highest values related to these properties were found in emmer bread, due to which in terms of these characteristics the quality of this product appears to be the lowest. Although statistically non-significant, these differences are consistent with the sensorial assessment and the values of the remaining physical indicators examined.

Table 5. Physicochemical assessment of bread $(\bar{x} \pm$ SD)

\begin{tabular}{|c|c|c|c|c|c|}
\hline Type of bread & $\begin{array}{l}\text { Moisture content } \\
\text { of crumb [\%] }\end{array}$ & $\begin{array}{l}\text { Cold bread } \\
\text { weight }[\mathrm{g}]\end{array}$ & $\begin{array}{c}\text { Loaf volume } \\
{\left[\mathrm{cm}^{3}\right]}\end{array}$ & $\begin{array}{c}\text { Volume of bread from } \\
100 \mathrm{~g} \text { flour }\left[\mathrm{cm}^{3}\right]\end{array}$ & $\begin{array}{c}\text { Specific weight } \\
\text { of crumb [n] }\end{array}$ \\
\hline Einkorn bread & $47.00^{\mathrm{a}} \pm 1.21$ & $213.57^{\mathrm{a}} \pm 5.20$ & $592.50^{\mathbf{b}} \pm 11.55$ & $381.46^{\mathrm{bc}} \pm 3.46$ & $0.38^{\mathrm{a}} \pm 0.01$ \\
\hline Emmer bread & $49.20^{\mathrm{a}} \pm 0.58$ & $204.96^{\mathrm{a}} \pm 4.62$ & $547.50^{c} \pm 6.93$ & $368.91^{\mathrm{c}} \pm 8.08$ & $0.38^{\mathrm{a}} \pm 0.01$ \\
\hline Spelt bread & $45.60^{\mathrm{bc}} \pm 1.06$ & $210.43^{\mathrm{a}} \pm 3.46$ & $625.00^{\mathrm{b}} \pm 8.66$ & $414.23^{\mathrm{b}} \pm 9.81$ & $0.35^{\mathrm{a}} \pm 0.01$ \\
\hline $\begin{array}{l}\text { Common wheat } \\
\text { bread ('Arkadia') }\end{array}$ & $48.45^{\mathrm{c}} \pm 1.76$ & $213.58^{\mathrm{a}} \pm 1.73$ & $862.50^{\mathrm{a}} \pm 5.77$ & $555.79^{\mathrm{a}} \pm 5.77$ & $0.22^{\mathrm{b}} \pm 0.01$ \\
\hline
\end{tabular}

$*$ the varied letters in the columns show significance of the differences at $\alpha=0.0$

Table 6. Texture Profile of bread crumb (after 24 hours for baking)

\begin{tabular}{|c|c|c|c|c|c|c|}
\hline Property & $\begin{array}{c}\text { Hardness } \\
{[\mathbf{N}]}\end{array}$ & $\begin{array}{c}\text { Adhesiveness } \\
{[\mathbf{m J}]}\end{array}$ & $\begin{array}{c}\text { Cohesive } \\
\text { ness }\end{array}$ & $\begin{array}{c}\text { Springiness/ } \\
\text { Elasticity }\end{array}$ & $\begin{array}{c}\text { Gumminess } \\
{[\mathbf{N}]}\end{array}$ & $\begin{array}{c}\text { Chewiness } \\
{[\mathbf{N}]}\end{array}$ \\
\hline Einkorn bread & $9.27^{\mathrm{b}}$ & 0.01 & $0.635^{\mathrm{c}}$ & 0.90 & $6.18^{\mathrm{b}}$ & $5.54^{\mathrm{b}}$ \\
\hline Emmer bread & $11.01^{\mathrm{b}}$ & 0.00 & $0.62^{\mathrm{bc}}$ & 0.92 & $6.85^{\mathrm{b}}$ & $6.31^{\mathrm{b}}$ \\
\hline Spelt bread & $12.39^{\mathrm{b}}$ & 0.04 & $0.519^{\mathrm{a}}$ & 0.96 & $6.43^{\mathrm{b}}$ & $6.11^{\mathrm{b}}$ \\
\hline $\begin{array}{c}\text { Common wheat bread } \\
\text { ('Arkadia') }\end{array}$ & $2.30^{\mathrm{a}}$ & 0.02 & $0.612^{\mathrm{b}}$ & 0.89 & $1.39^{\mathrm{a}}$ & $1.25^{\mathrm{a}}$ \\
\hline Total groups & 8.50 & 0.02 & 0.595 & 0.92 & 4.98 & 4.59 \\
\hline
\end{tabular}

* the varied letters in the columns show significance of the differences at $\alpha=0.05$

\section{CONCLUSIONS}

Einkorn flour dough and emmer flour dough were found to present poor tolerance to mechanical processing and prolonged fermentation. As for spelt flour dough, the findings show the optimum duration of fermentation amounting to 60 minutes, respectively. In terms of technological and baking properties, spelt flour was most similar to the flour obtained by milling common wheat. Differences were observed in the baking process and the quality of the obtained products in relation to the type of flour from ancient wheat varieties (einkorn, emmer, spelt). The fast one-stage baking process was found to be highly effective in the case of spelt and einkorn breads. Since the processing of einkorn dough posed difficulties, it is suggested that this type of bread dough be prepared with an addition of substances enhancing its structure (e.g. ascorbic acid). The findings related to emmer bread, namely the poor efficiency of the one-stage baking process, the small volume and defective porosity, disqualifying this type of bread, suggest a need to use a different baking method. Use of a pre-ferment seems to be a good solution in this case. The doughs made from flour obtained from the ancient wheat varieties required gentle manual or mechanical processing, at low rotation of dough hooks and for a hort duration (3-4 min). The breads made from ancient wheat varieties generally presented inferior quality, compared to the loaves made from conventional wheat flour, however, given the specific pleasant taste and aroma of the former, as well as attractive colour in the case of einkorn bread, these baked products may be an interesting addition to the assortment of breads on offer from bakeries, restaurants, agritourist farms, etc. 


\section{REFERENCES}

1. Abdel-Aal E.S.M., Hucl P., Sosulski F.W. \& Bhirud P.R. 1997. Kernel, milling and baking properties of spring - type spelt and einkorn wheats. Journal of Cereal Science, 3(26): 363370.doi.org/10.1006/jcrs.1997.0139.

2. Achremowicz B., Kulpa D. \& Mazurkiewicz J. 1999. Technologiczna ocena ziarna pszenic orkiszowych. Zeszyty Naukowe AR Kraków, 360: 11-17.

3. Ambroziak Z. 1999. Produkcja piekarsko - ciastkarska. Cz.2. Wydawnictwo Szkolne i Pedagogiczne, Warszawa.

4. Belcar J., Sobczyk A., Sobolewska M., Stankowski S. \& Gorzelany J. 2020. Characteristics of technological propreties of grain and flour from ancient varieties of wheat (einkorn, emmer and spelt). Acta Universitats Cibiniensis. Series E: Food Technology. 24(2): 269-278. https://doi.org/10.2478/aucft-2020-0024.

5. Bojňanská T. \& Frančáková H. 2002. The use of spelt wheat (Triticum spelta L.) for baking applications. Rostlinná Výroba, 48(4): 141-147.

6. Brabender 2009. Materiały instruktażowe - Ekstensograf.

7. Brabender 2008. Materiały instruktażowe - Farinograf.

8. Ceglińska A. 2003. Technological value of a spelt and common wheat hybrid. Electronic Journal of Polish Agricultural Univertities. Series Food Science and Technology, 6(1).

9. Corbellini M., Empilli S., Vaccino P., Brandolini A., Borghi B., Heun M., Salamini F. 1999. Einkorn characterization for Bread and Cookie Production in Relation to Protein Subunit Composition. Cereal Chemistry, 76(5): 727-733. https://doi.org/10.1094/CCHEM.1999.76.5.727.

10. Dąbkowska E. 2009. Wpływ odmiany ziarna orkiszu uzyskanego w warunkach produkcji ekologicznej na jakość mąki. Praca doktorska przygotowana na Wydziale Nauki o Żywności Uniwersytetu Warmińsko Mazurskiego w Olsztynie.

11. Dziki D., Siastała M. \& Laskowski J. 2011. Ocena właściwości fizycznych pieczywa handlowego. Acta Agrophysica, 18 (2): 235-244.

12. Filipčev B., Šimurina O. \& Bodroža - Solarov M. 2014. Combined effect of xylanase, ascorbic and citric acid in regulating the quality of breadmade from organically grown spelt cultivars. Journal of Food Quality. 37: 185-195. 10.1111/jfq.12081.

13. Gambuś H., Zięć G., Litwinek D., Drużkowska M., Gambuś F. \& Mickowska B. 2018. Porównanie wartości wypiekowej mąki z pszenicy orkiszowej z mąką z pszenicy zwyczajnej. ŻYWNOŚĆ. Nauka. Technologia. Jakość, 25, 1 (114): 30-49. DOI 10.15193/zntj/2018/114/219.

14. Geisslitz S., Wieser H., Scherf F.A. \& Koehler P. 2018. Gluten protein composition and aggregation properties as prediction of bread volume of common wheat, spelt, durum wheat, emmer and einkorn. Journal of Cereal Science, 83: 204-212. https://doi.org/10.1016/j.jcs.2018.08.012.

15. Guerrini L., Parenti O., Angeloni G. \& Zanoni B. 2019. The breadmaking proces of ancient wheat. A semistructured interview to bakes. Journal of Cereal Science, 87: 9-17. doi.org/10.1016/j.jcs.2019.02.006.

16. ICC, 1992. International Association For Cereal Science And Technology (ICC) Standard Method No. 115/1. Method for using the Brabender Farinograph. ICC Secretariat, Vienna.

17. ICC, 1992. International Association for Cereal Science and Technology (ICC) Standard Method No. 114/1. Method for using the Brabender Extensograph. ICC Secretariat, Vienna.

18. Jakubczyk T. \& Haber 1983. Analiza zbóż i przetworów zbożowych. Wydawnictwo SGGW - AR. Warszawa.

19. Jakubczyk T. 1974. Ćwiczenia z Technologii Zbóż. Dział Wydawnictw, Warszawa.

20. Kissing Kucek L., Dyck E., Russell J., Clark L., Hamelman J., Burns-Leader S., Senders S., Jones J., Benscher D., Davis M., Roth G., Zwinger S., Sorrells M. \& Dawson J.C. 2017. Evaluation of wheat and emmer varietes for artisanal baking, pasta making and sensory quality. Journal of Cereal Science, 74; 1927. https://doi.org/10.1016/j.jcs.2016.12.010.

21. Krawczyk P., Ceglińska A. \& Izdebska K. 2008a. Porównanie właściwości reologicznych ciasta i jakości pieczywa otrzymanego z mąki orkiszu i pszenicy zwyczajnej. ŻYWNOŚĆ. Nauka. Technologia. Jakość., 4 (59): 141-151.

22. Krawczyk P., Ceglińska A. \& Kardialik J. 2008b. Porównanie wartości technologicznej ziarna orkiszu z pszenicą zwyczajną. ŻYWNOŚĆ. Nauka. Technologia. Jakość., 5 (60): 43-51.

23. Krełowska - Kułas M. 1993. Badanie jakości produktów spożywczych. Państwowe Wydawnictwo Ekonomiczne, Warszawa. 
24. Lomolino G., Morari F., Dal Ferro N., Vincenzi S. \& Pasini G. 2017. Investigating the einkorn (Triticum monococcum) and common wheat (Triticum aestivum) bread crumb structure with X-ray microtomography effects on rheological and sensory properties. International Journal of Food Science and Technology, 52: 1498-1507. doi:10.1111/ijfs.13425.

25. Macaroni E., Carcea M., Schiavone M. \& Cubadda R. 2002. Spelt (Triticum spelta L.) pasta quality: combined effect of flour properties and drying conlitions. Cereal Chemistry, 79: 634-639. doi.org/10.1094/CCHEM.2002.79.5.634.

26. Majewska K., Dąbkowska E., Żuk - Gołaszewska K. \& Trybulski J. 2007. Wartość wypiekowa mąki otrzymanej z ziarna wybranych odmian orkiszu (Triticum spelta L.). ŻYWNOŚĆ. Nauka. Technologia. Jakość. 2(25): 60-71.

27. Marchand B. 2014. Samopsza - czyli o pszenicy numer jeden - najstarszej, pierwszej udomowionej, jednoziarnistej... Przeglad Zbożowo - Młynarski, 58, 06: 23-15.

28. Michalska - Pożoga I. \& Raczkowska A. 2012. Pakowanie w atmosferze modyfikowanej a jakość ekologicznego pieczywa orkiszowego. Postępy Techniki Przetwórstwa Spożywczego, 2: 60-63.

29. Polska Norma PN-A-74108:1996. Pieczywo - Metody badań.

30. Pruska - Kędzior A., Kędzior Z. \& Klockiewicz - Kamińska E. 2008. Comparison of viscoelastic properties of gluten from spelt and common wheat. European Food Research Technology, 227: 199-207. DOI: $10.1007 / \mathrm{s} 00217-007-0710-0$.

31. Romankiewicz D., Cacak - Pietrzak G. \& Kania K. 2014. Wpływ metody prowadzenia ciasta na zmiany tekstury przechowywanego pieczywa pszennego. Zeszyty Problemowe Postępów Nauk Rolniczych, 579: 67-77.

32. Romankiewicz D., Ceglińska A., Cacak - Pietrzak G. 2013. Wpływ metody prowadzenia ciasta na jakość chleba pszennego. Zeszyty Problemowe Postępów Nauk Rolniczych, 574: 57-65.

33. Różyło R. 2010. Wpływ parametrów obróbki ciasta na cechy fizyczne chleba pszennego. Acta Agrophysica, 16(1): 149-161.

34. Różyło R. \& Laskowski J. 2009. Porównanie cech jakościowych chleba pszennego wypieczonego z ciasta prowadzonego jednofazowo i dwufazowo. ŻYWNOŚĆ. Nauka. Technologia. Jakość. 5(66): 83-95.

35. Sahin Y., Yildirim A., Yucesan B., Zencirci N., Erbayran S. \& Gurel E. 2017. Phytochemical content and antioxidant activity of einkorn (Triticum monococcum ssp. monococcum), bread (Triticum aestivum L.) and durum (Triticum durum Desf.) wheat. Progress in Nutrition, 19 (4): 450-459. https://doi.org/10.23751/pn.v19i4.5847.

36. Saparistein H.D., Siddhu S. \& Aliani M. 2012. Discrimination of Volatiles of Refined and Whole Wheat Bread Containing Red and White Wheat Bran Using and Electronic Nose. Journal of Food Science, 77, 11: S399-S406. DOI: 10.1111/j.1750-3841.2012.02952.x.

37. Sobczyk A., Pycia K., Stankowski S., Jaworska G. \& Kuźniar P. 2017a. Evaluation of the rheological properties of dough and quality of breadmade with the flour obtained from old cultivars and modern breeding lines od spelt (Triticum aestivum ssp.spelta). Journal of Cereal Science, 77: 35-41. doi.org/10.1016/j.jcs.2017.07.013

38. Sobczyk A., Pycia K., Jaworska G. \& Kaszuba J. 2017b. Comparison of fermentation strength of the flours obtained from the grain of old varieties and modern breeding lines of spelt (Triticum aestivum ssp. spelta). Journal of Food Processing and Preservation, 41e13293: 1-6. DOI: 10.1111/jfpp.13293.

39. Sołtysek K. 2011. Poradnik do ćwiczeń laboratoryjnych z wybranych zagadnień technologii przemysłu spożywczego. Przemysł zbożowo - młynarski, piekarniczy i cukierniczy. Wydawnictwo Uniwersytetu Ekonomicznego, Wrocław.

40. Stallknecht G.F., Gilbertson K. M. \& Ranney J. E. 1996. Alternative wheat cereals as food grains: Einkorn, emmer, spelt, kamut and triticale. In: J. Janisck (ed. ) Progress in new crops. ASHS Press, Alexandria, VA. 156-170.

41. Stępniewska S. \& Słowik E. 2016. Ocena wartości technologicznej wybranych odmian pszenicy ozimej i jarej. Acta Agrophysica, 23(2): 275-286.

42. Troccoli A. \& Codianni P. 2005. Appropriate seed ingrate for einkorn, emmer and spelt grown under rainfed condition in southern Italy. European Journal of Agronomy, 22: 293-300. DOI: 10.1016/j.eja.2004.04.003.

43. Valli V., Taccari A., Di Nunzio M., Danesi F. \& Bordoni A. 2018. Health benefits of ancient grains. Comparison among bread made with ancient, heritage and modern grain flours in human cultured cells. Food Research International, 107: 206-215. DOI: 10.1016/j.foodres.2018.02.032.

44. Zieliński H., Ceglińska A. \& Michalska A. 2008. Bioactive compounds in spelt bread. European Food Research Technology, 226: 537-544. DOI:10.1007/s00217-007-0568-1. 